\title{
1 Identification of eroded areas using remote sensing in a badlands landscape on marls in the central Spanish Pyrenees
}

$4 \quad$ L.C. Alatorre ${ }^{*}, 1, \mathrm{~S}$. Beguería $^{2}$

$6 \quad{ }^{1}$ Instituto Pirenaico de Ecología (CSIC), Zaragoza (Spain).

$7 \quad 2$ Aula Dei Experimental Station (CSIC), Zaragoza (Spain).

8

9 * Corresponding author: Luis-Carlos Alatorre, Instituto Pirenaico de Ecología (CSIC), Avda. Montañana 10 1005, 50059 - Zaragoza (Spain). PO Box 202, 50080 - Zaragoza (Spain). Telf.: +34 976 716034; Fax: +34

11976 716019; E-mail: lalatorre@ipe.csic.es

13 Abstract

14 Identification of erosion areas on a regional scale can be very useful for environmental planning, and can

15 help reduce land degradation and sediment yield to streams and reservoirs. Remote sensing techniques were 16 used to determine erosion and erosion risk areas in a badlands landscape in the Ésera River catchment 17 (Spanish Pyrenees). The size, sparse vegetation cover, and high erosion level in the badlands, enabled good 18 visual and digital discrimination relative to other land covers and surfaces. A maximum likelihood 19 supervised method was used to discriminate heavily eroded areas (badlands) from sparse or densely 20 vegetated lands, based on the spectral signature of bare soil on marls. The classification distance was 21 obtained for each pixel and used to determine erosion areas and areas at risk of erosion. Two classification 22 performance statistics (sensitivity and specificity) where used to determine appropriate threshold values. 
23 This showed that most erosion risk areas coincided with low vegetation cover surrounding the badland 24 areas.

25 Key words: badlands, marls, regolith, classification performance, sensitivity and specificity, supervised classification.

\section{Introduction}

Maps of active erosion areas and areas at risk of erosion are of great potential use to environmental

31 (governmental and private) agencies, as they allow erosion prevention efforts to be concentrated in those 32 places where the benefit will be highest. There is no single straightforward method for assessing erosion, and erosion evaluation is highly dependent on the spatial scale and the purpose of the assessment (Warren,

34 2002). For limited spatial scales (<100 ha), field surveys can provide an accurate means of analyzing erosion damage (Herweg, 1996). However, for focal area selection over larger areas other approaches that integrate available spatial data need to be applied. Studies on erosion undertaken at spatial scales covering

37 local to regional areas (Vrieling et al., 2006) have provided both quantitative information (e.g., erosion rates) and qualitative information (e.g., erosion risk areas).

Methods for evaluating erosion risk on catchment and regional scales (10 to $10,000 \mathrm{~km}^{2}$ ) include the application of erosion models or qualitative approximations using remote sensing and geographic

41 information (GIS) technologies. Merrit et al. (2003) have exhaustively described current erosion models.

42 However, model application outside the regions for which it was developed has generally led to error (e.g.,

43 Brazier et al., 2000), and in many cases long and complex processes of calibration have been necessary to 44 enable models to be adapted to particular study areas (Jetten et al., 1999, 2003). In many cases erosion 45 models have been created for use at small scales, so their extrapolation to larger scales (catchment or 
regional) is very complex and sometimes erroneous (Kirkby et al., 1996; Schoorl et al., 2000; Yair and RazYassif, 2004).

The use of remote sensing and GIS techniques has been shown to have potential for erosion assessment on regional scales, including identification of eroded surfaces, estimation of factors that control erosion, investigation of soil and vegetation characteristics, and monitoring the advance of erosion over time

51 (Muchoney and Haack, 1994; Lambin, 1996). In most cases remote sensing techniques have been applied simply to identify the characteristics (or the absence) of vegetation cover, largely because of limited visibility of the soil surface in humid and sub-humid environments (Vrieling, 2006).

Other studies have demonstrated the potential of remote sensing techniques in determining temporal and spatial erosion patterns, as well as in qualitative estimation of areas of active erosion and erosion risk areas (Pilesjo, 1992; Rode and Frede, 1997; Metternicht and Fermont, 1998; Szabo et al., 1998; Millward and Mersey, 1999; Reusing et al., 2000; Haboudane et al., 2002; Metternicht and Gonzalez, 2005). Calculation of the percentage of bare soil has also been used to estimate erosion risk (e.g., de Jong, 1994; Paringit and Nadaoka, 2003). This type of methodology has improved detection of erosion areas by the use of high resolution spectral images (MERIS, Landsat, and SPOT) in combination with other layers of thematic information including slope, rainfall, and soil type (Mathieu et al., 1997; Haboudane et al., 2002; Singh et al., 2004). For example, Amissah-Arthur et al. (2000) used SPOT data in combination with biophysical (e.g., soil quality) and socioeconomic data (e.g., land use intensity, population density, carrying capacity, and agricultural intensity) to assess land degradation status in the African Sahel.

Other methodologies applied to inventories and monitoring of the activity of different erosion processes include band ratios (Pickup and Nelson, 1984; Frazier and Cheng, 1989), vegetation indices (Pickup and Chewings, 1994; Tripathy et al., 1996), combinations of reflective and microwave data (Koopmans and Forero, 1993; Singhroy, 1995; García-Meléndez et al., 1998; Metternicht and Zinck, 1998; 
Singhroy et al., 1998), and combinations of remote sensing data and other geocoded information (Floras and Sgouras, 1999; Mati et al., 2000; Giannetti et al., 2001; Shrimalil et al., 2001; Zinck et al., 2001; Haboudane

71 et al., 2002; Ma et al., 2003; Symeonakis and Drake, 2004).

Various studies in the Spanish Pyrenees have estimated erosion at regional (Beguería, 2005 and 2006) and catchment scales (Fargas et al., 1997) using remote sensing and erosion models to i) qualitatively estimate different levels of erosion risk, ii) identify zones with different erosion risk, and, iii) formulate empirical models for predicting erosion risk. These studies have shown that the badland systems on Eocene marls are areas with accelerated erosion processes, and constitute the main sediment sources in the Pyrenees, with very important consequences for the silting of reservoirs (Valero-Garcés et al. 1999).

The term badlands is used to describe areas of unconsolidated sediment or poorly consolidated bedrock, with little or no vegetation (Gallart et al., 2002). Such areas are commonly affected by intense soil erosion processes including gulling, rilling, and sheet wash erosion (Nadal-Romero et al., 2008). Badlands develop in a wide range of climatic zones, particularly in semiarid areas, and to a lesser extent in humid and sub-humid regions (Bryan and Yair, 1982; Campbell, 1989; Regüés, 1995; Regüés et al., 1995; Pardini, 1996; Torri and Rodolfi, 2000). Badlands are typically associated with accelerated erosion and consequent unstable landscapes (Morgan, 1997), so that their fixation or limitation require considerable effort. In subhumid regions, the development of badlands is favored by lithological and topographical factors (Morgan, 1997; Oostwoud-Wijdenes et al., 2000), and seasonal climatic variability. The latter effect is especially pronounced in areas characterized by strong intra-annual contrasts in temperature and rainfall distribution. For example, freeze-thaw cycles in winter, and wetting-drying in spring-summer, are the main processes involved in regolith weathering, thereby controlling slope development in combination with rainfall-related erosion processes. When these factors are coupled with the presence of rocks that are highly susceptible to 
91 erosion, the resulting geomorphological dynamics are extremely active (Regüés et al., 1995; Nadal-Romero 92 et al., 2007).

The objective of this study was to develop a method for identification and spatial analysis of areas of

.
severe erosion degradation (badlands), and areas of erosion risk associated with low vegetation cover. The study focused on the Eocene marls located in the middle section of the Ésera River basin, in the central Spanish Pyrenees. The method involved the application of remote sensing techniques (supervised classification to discriminate areas with active erosion), implementation of a ROC (receiver operating characteristic) curve to select a classification threshold, and assessment of the level of uncertainty associated with predictions. This approach has been used in other studies because, in regions where the land is naturally covered by vegetation, any lack of vegetation or exposure of earth are clear indicators of active erosion. Thus, the classification used was directed at detection of areas where the substrate was exposed, and spectrally similar areas were regarded as vulnerable to erosion.

\section{Study area}

The study area is located approximately $23 \mathrm{~km}$ north of the Barasona reservoir, in the Spanish Pyrenees, and is an integrated badlands landscape developed on Eocene marls orientated north-southeast (Fig.1) at $620 \mathrm{~m}$ to $2149 \mathrm{~m}$ (Fig. 2) altitude. The badlands system is conformed by a group of typical hillside badlands developed on sandy marls with clay soil, and is strongly eroded over convex hillsides with a moderately inclined slope. Runoff from this area enters the Viu and Rialvo rivers in the catchment of the Ésera River, and the Viyacarti River in the catchment of the Isábena River.

The soils in the study area are chromic vertisoils with an A-B-C profile, an ochric surface horizon, and a C horizon more than one meter deep. The original parent material is rich in calcium carbonate, 
114 accumulated in the form of nodules in the B and C horizons. A significant feature is the formation of cracks 115 (sometimes more than $1.5 \mathrm{~m}$ deep) arising from shrinkage in the dry season, and these enable mixing of the 116 upper horizon.

117 The climate is defined as mountainous, humid, and cold, with influences from the Atlantic Ocean 118 and the Mediterranean Sea (García-Ruíz et al., 1985). The average annual temperature is $11^{\circ} \mathrm{C}$, and the 119 average annual precipitation is approximately $876 \mathrm{~mm}$ (Fig. 3). Precipitation is irregular throughout the 120 year, with a maximum in spring between 80 and $70 \mathrm{~mm}$ (April and May, respectively), and a minimum in 121 July-August when precipitation does not exceed $70 \mathrm{~mm}$.

\section{Data and methods}

\subsection{Data selection and preparation}

One limitation of satellite images is that they are affected by radiometric interference including solar rays and the atmospheric conditions. This problem is usually resolved in images of high temporal and spatial resolution (e.g., NOAA-AVHRR) by the creation of multi-temporal compound images and filtration 130 (Gutman et al., 1995). In the case of images with high spatial resolution (such as those of Landsat) and low 131 temporal frequency it is necessary to make more complex corrections.

In this study Landsat data (spatial resolution $30 \mathrm{~m}$ ) from August 2006 were used because of the 133 lower frequency of cloud cover in this month (Fig. 1A). The image was geometrically corrected using 134 control points and the algorithm developed by Pala and Pons (1996) implemented in the Miramon software, 135 which accounts for topographic distortion by incorporation of a digital terrain model (DTM). 
The atmospheric effect on the electromagnetic signal was corrected using the radiative transfer code

137 6S (Vermote et al., 1997). Illumination conditions were corrected to compensate for differences caused by

138 the irregularity of the terrain. The anisotropic reflectance model was used as this is more robust than

139 Lambert's reflectance model (Riaño et al., 2003). A more detailed description of the process of radiometric 140 and geometric image correction is provided by Vicente-Serrano et al. (2008). Any areas affected by clouds

141 in the corrected images were eliminated through visual recognition.

3.2. Classification procedure

\subsubsection{Definition of the thematic categories and training areas}

An important objective was to define areas of the Landsat scene representing thematic categories 148 with maximum spectral heterogeneity present in the scene. Although the main objective of the study was 149 identification of active erosion and erosion risk areas, for the classification algorithm it was necessary to 150 establish a priori categories that adequately represented the variability of land cover types present in the

151 area. This is because the algorithm of maximum likelihood considers not only the average characteristics of 152 the spectral signature of each category, but also the covariance among categories, allowing for a more 153 precise discrimination.

Aerial orthophotos (SIGPAC, 2003) were used in the establishment of thematic categories in the 155 scene, and also in the selection of training areas for each thematic category. A spectral signature and a 156 matrix of contingency, generated using Erdas 8.7 software, were used to determine the degree of 157 discrimination among categories. 


\subsubsection{Image classification and validation}

Image classification was based on the method of supervised maximum likelihood from the set of

thematic categories. The discriminatory capacity of the classification model was determined from a confusion matrix over the training samples. After verifying the adjustment of training samples, a spectral distance map was obtained for the badlands category. This map represents the distance between the spectral signature of each pixel and that of the badland category. From the spectral distance map, maps of active erosion (badlands) and erosion risk areas were prepared by setting a classification threshold. For 167 construction of the ROC curve, and also for validating the final classification, an independent sample of 150 168 randomly distributed points were visually classified using aerial orthophotos (SIGPAC, 2003).

Determination of the classification threshold for the construction of maps of active erosion and 170 erosion risk areas was based on the ROC curve, a method coming from the signal processing theory and 171 adapted to environmental applications afterwards (Beguería, 2006a). The ROC curve is constructed by

172 calculating, for each classification threshold, the sensitivity and specificity of the resulting classification:

173 sensitivity $=\frac{a}{a+c}$

$174 \quad$ specificity $=\frac{b}{b+d}$,

175 where $a$ and $d$, respectively, are the true positives and true negatives, and $b$ and $c$ the false positives and 176 false negatives, respectively (Table 1).

The sensitivity of the model is the proportion of positive pixels correctly predicted, or the probability 178 that a pixel belonging to a particular category is correctly predicted. The specificity of the model is the 179 proportion of negative pixels correctly predicted, or the probability that a pixel not belonging to a particular 180 category is correctly predicted. Thus, models with high sensitivity are characterized by ability to correctly 
181 predict positive pixels or pixels belonging to the category of interest, whereas models with high specificity 182 are those able to correctly predict negative pixels or pixels not belonging to the category of interest. High 183 sensitivity is usually associated with poor specificity, evident as an overestimate of the areas belonging to 184 the category of interest. An optimum model would be one with a highest possible value of both sensitivity 185 and specificity. The sensitivity and specificity statistics provide information on the degree of uncertainty in 186 the classification. Specifically, the values (1-sensitivity) and (1-specificity) represent the probabilities of 187 committing an error of omission (type II error, or false negative) and an error of commission (type I error, or 188 false positive), respectively (Table 1). Other common statistics of the classification model, such as overall 189 reliability, are biased estimates that depend on the proportion of pixels actually belonging to each category, 190 and therefore should not be used for comparison between different case studies (Beguería, 2006b). The 191 overall reliability is defined by equation 3:

$192 \quad$ reliability $=\frac{a+d}{a+b+c+d}$

The ROC curve method allows the degree of uncertainty associated with a specific classification 194 threshold to be determined. For identification of active erosion areas (badlands) a classification threshold 195 was fixed to be equal to the spectral distance for which the sensitivity of the model was 0.9 , corresponding 196 to a $10 \%$ probability of an error of omission. For identification of erosion risk areas a classification 197 threshold was fixed that was equal to the spectral distance for which the sensitivity and specificity were 198 approximately equal. 
The topographic characteristics of the areas classified as badlands and erosion risk areas were 203 analyzed, as were the slope and aspect (derived from the DTM), and the variance of these properties 204 between the two categories and the whole study area, were derived.

\section{Results and Discussion}

\subsection{Selection of categories and training areas}

The definition of thematic categories and selection of training areas were based on visual analysis of 211 aerial orthophotos (SIGPAC, 2003). The thematic variability of the study area comprised five categories: 212 erosion active areas (badlands), scrubland, grassland, conifers, and deciduous forest. The training areas were 213 used to obtain spectral signatures for each thematic category (Fig. 4). The badlands were characterized by 214 high brightness values for all bands, and had greater spectral variability.

Discrimination among the different spectral signatures was good with the exception of band 5 216 (SWIR), where the values for average reflectivity of badlands, scrubland, and grassland were very similar.

217 Because of the response of Landsat band 5 to variation in soil moisture and vegetation biomass (Chuvieco, 218 1996), it is likely that in August 2006 the badlands and scrubland, and to a smaller degree the grassland, had 219 similar moisture conditions. In the badland areas of the sub-humid climate zone, the lack or sparseness of 220 vegetation is because of difficulties in vegetation colonization of the very unstable hillsides, which occurs 221 because of the dynamic geomorphology of the area during most of the year (Solé et al., 1997). In the central 222 Pyrenees the distribution of scrub is very diffuse, as a consequence of spatial differences in the rates of 223 vegetation succession over recent decades (Vicente-Serrano, 2006). Colonization of bare soil areas is 224 slower, resulting in scrub areas with low vegetation cover (Pueyo and Beguería, 2007). Vegetation cover has 
been stable in the central Pyrenees between 1990 and 2000, with only $0.9 \%$ of the area in the process of scrub colonization.

The contingency matrix obtained for the sampling areas, using the maximum likelihood classification algorithm, showed that all categories had a 90\% success value (Table 2). In the case of the badlands there was a confusion level of $1 \%$ in the scrubland category, confirming the uncertainty associated with transition areas.

\subsection{Thematic classification}

A land cover map was obtained from the classification algorithm (Fig. 5), and validation using the independent random sample showed a global reliability of $81.83 \%$. The grassland category was the worst discriminated, with an omission error of $14.04 \%$ (sensitivity $=0.860$ and specificity $=0.742$ ) $($ Table 3 ), whereas deciduous forest was the best discriminated, with a commission error of only 6.25\%. The classification model had a probability of omission error of $12.90 \%$ with respect to the badlands category (sensitivity $=0.871$ ), but classification of the badlands involved some scrub areas that were incorrectly classified, resulting in a commission error of $22.86 \%$ (specificity $=0.771$ ).

242 forest $21 \mathrm{~km}^{2}$, grassland $32 \mathrm{~km}^{2}$, and scrubland $99 \mathrm{~km}^{2}$. It was also evident that the areas occupied by scrub 243 and grass bordered areas classified as badlands (Fig. 6). This spatial distribution suggests that there is a 244 progressive transition between eroded areas and forest. 
Once the image classification procedure had been validated, identification of badlands and risk erosion areas was performed by using only the spectral distance map generated in the initial classification, showing the badlands category (Fig. 7). The map of spectral distance is an intermediate requirement in the process of supervised classification, and is used to assign each pixel to the category of greatest similarity (smaller spectral distance). However, as the main focus of this study was on a single category, a more precise result was obtained using the map of spectral distance in conjunction with a user-determined classification threshold. The spectral distance as determined by the maximum likelihood method has the advantage of not using the linear or euclidean distance between the centers of the spectral signatures, but to be based on the variance/covariance matrix among all spectral signatures, thus resulting in a much more 257 precise distance statistic.

The ROC curve for the badlands had a medium-to-high discrimination capacity (Fig. 8). The ROC curve shows the values of sensitivity and specificity associated with different possible values for the classification threshold. Determination of the classification threshold requires a compromise between sensitivity and specificity, as it is impossible to maximize both at the same time. Thus, a high sensitive classification threshold (i.e., one yielding a very low omission error) will be associated with moderate specificity values, and results in an overestimate of the area belonging to the badlands category. The opposite result would be obtained by setting a high specific threshold.

We selected a model with a high specificity (0.900) to minimize commission errors (false positives). This is a common approach in statistical analysis, equivalent to selection of a confidence level of $\alpha=0.1$.

267 For the spatial delimitation of erosion risk areas a classification threshold value was chosen that resulted in approximately equal values for sensitivity and specificity (0.750 and 0.710 , respectively). The application of both classification thresholds to the map of spectral distance for the badlands category allowed producing maps for the active erosion and risk erosion areas (Fig. 9), with surface areas of 
271 these categories of $17 \mathrm{~km}^{2}$ and $49 \mathrm{~km}^{2}$, respectively. The surface area of active erosion for the badlands 272 category was the same as that from the land cover map generated previously. Visual comparison of the maps 273 showed that the erosion risk areas corresponded to the scrubland category (and in some cases the grassland

274 and conifer categories) bordering the badlands areas. These areas had spectral characteristics intermediate 275 between badlands and scrubland, indicating either a mixture of the categories within the pixel or an 276 intermediate level of degradation. Both possibilities are consistent with classification of the above categories 277 as erosion risk areas.

The DTM morphological analysis showed a predominance of north (33\%) and south (45\%) 279 orientations over the study area (Fig. 10A). The badland areas occurred predominantly on hillsides oriented 280 to the north (44\%), whereas the erosion risk areas had a distribution similar to the total study area (Fig. 10, 281 C and B). The markedly different distribution of badlands relative to other categories in the study area suggests that different erosion processes are active in opposing hillside orientations. The aspect angle is a determining factor in the dynamics, intensity, and effectiveness of weathering processes in badland areas developing in mountainous sub-humid regions (Nadal-Romero et al., 2007). This is a consequence of regolith weathering dynamics arising from climatic factors (particularly freeze-thaw processes involving cryoclastism, cryosuction, and ice growth) on north-orientated hillsides, whereas on south-orientated

287 hillsides the most effective weathering process is thermoclastism, which is related to high daily temperature variations (Nadal-Romero et al., 2006). Confirmation of this effect would suggest that areas at risk with a north orientation should be a focus for erosion risk mitigation efforts.

The frequency distribution of the slope in each category was also analyzed (Fig. 11), but there were no significant differences among the badlands, erosion risk areas, and the total study area. 
This study has demonstrated the utility of remote sensing and GIS techniques in basic and applied geomorphological research, both at watershed and regional scales (study areas between 10 and 10,000 $\mathrm{km}^{2}$ ). The use of a supervised classification method using the maximum likelihood algorithm on a set of a priori categories enabled reliable mapping of areas with active erosion and vegetation. Selection of training areas using aerial orthophotos (SIGPAC, 2003) enabled identification of areas in each of the designated categories, based on maximum variability among spectral signatures. The use of an independent set of randomly selected pixels allowed for validating the classification model, which was very good (82\% overall 302 accuracy).

The use of an ROC curve to assess uncertainty in the classification model (based on the magnitude of omission and commission errors) allowed classification thresholds for the active erosion and erosion risk areas to be determined. It was found that $7 \%$ of the surface area was affected by active erosion processes that resulted in a morphology typical of badlands, and $21 \%$ of the surface area was classified as at risk of erosion. This suggests that there was a high degree of uncertainty in the spectral signatures of pixels separating badlands from other areas. These are erosion risk areas, either through intensification of erosion processes or because of head erosion in headwaters in the adjacent badlands. The erosion risk areas bordering the badlands coincided with transition zones from badlands to forest, where the soil was poorly 311 covered by vegetation (10-50\% cover). These are marginal areas with slopes greater than $15 \%$, where the 312 establishment of vegetation is very difficult.

Finally, DTM was found to be a useful primary tool for morphological exploration of active erosion 314 areas and erosion risk areas. In the study area, asymmetry in the development of badland areas was deduced 315 from the orientation, with more development of badlands on shady hillsides because of weathering. In contrast, hillside slope did not appear to have a significant effect on badlands formation in the study area. 


\section{Acknowledgments}

This research was financially supported by the project "Processes and sediment balances at different

321 spatial scales in Mediterranean environments: Effects of climate fluctuations and land use changes" 322 (CGL2006-11619/HID), funded by CICYT, Spanish Ministry of Education and Science. The contribution of 323 the first author has been possible thanks to a scholarship granted by The National Council for Science and 324 Technology of Mexico (CONACYT). This work would not have been possible without the collaboration of 325 Dr. Sergio Vicente Serrano, who kindly provided the Landsat TM image, both radiometrically and 326 geometrically corrected.

\section{$328 \quad$ References}

Amissah-Arthur, A., Mougenot, B., Loireau, M., 2000. Assessing farmland dynamics and land degradation on Sahelian landscapes using remotely sensed and socioeconomic data. International Journal of Geographical Information Science, 14: 583-599.

Beguería, S., 2005. Identificación y Características de las Fuentes de Sedimento en Áreas de Montaña: Erosión y Transferencia de Sedimento en la Cuenca Alta del Río Aragón. Instituto Pirenaico de Ecología, Zaragoza.

Beguería, S., 2006a. Identifying erosion areas at basin scale using remote sensing data and GIS. International Journal of Remote Sensing, 20: 4585-4598.

338 Beguería, S., 2006b. Validation and evaluation of predictive models in hazard assessment and risk management. Natural Hazards, 37(3): 315-329. 
Brazier, R.E., Beven, K.J., Freer J.F., Rowan, J.S., 2000. Equifinality and uncertainty in physically based soil erosion models: application of the GLUE methodology to WEPP (the Water Erosion Prediction Project) for sites in the UK and USA. Earth Surface Processes and Landforms, 25: 825-845.

Bryan, R., Yair, A., 1982. Perspectives on studies of badland geomorphology. In: R., Bryan, A., Yair (eds.), Badland Geomorphology and Piping. Geobooks, Norwich, pp. 1-12.

Campbell, I.A., 1989. Badlands and badland gullies. In: D.S.G., Thomas (Ed.), Arid Zone Geomorphology. Belhaven, London, UK, pp. 159-183.

Chuvieco, E., 1996. Fundamentos de teledetección espacial. Ediciones RIALP, S.A. Madrid, España, Segunda edición, 451 pp.

De Jong, S.M., 1994. Applications of Reflective Remote Sensing for Land Degradation Studies in a Mediterranean environment. PhD Dissertation Thesis, Nederlandse Geografische Studies 177, Utrecht, The Netherlands, 179 pp.

Fargas, D., Martínez-Casasnovas, J.A., Poch, R.M., 1997. Identification of critical sediment source areas at regional level. Physics and Chemistry of the Earth, 22: 355-359.

Floras, S.A., Sgouras, I.D., 1999. Use of geoinformation techniques in identifying and mapping areas of erosion in a hilly landscape of central Greece. International Journal of Applied Earth Observation and Geinformation, 1: 68-77.

Frazier, B.E., Cheng, Y., 1989. Remote sensing of soils in the eastern Palouse region with Landsat Thematic Mapper. Remote Sensing of Environment, 28: 317-325.

Gallart, F., Llorens, P., Latron, J., Regües, D., 2002. Hydrological processes and their seasonal controls in a small Mediterranean mountain catchment in the Pyrenees. Hydrology and Earth System Sciences, 6(3): 527-537. 
García-Ruiz, J.M., Puigdefábregas, J., Creus, J., 1985. Recursos hídricos Superficiales del Alto Aragón. Instituto de Estudios Altoaragoneses, 224 pp., Huesca.

García-Meléndez, E., Molina, I, Ferré-Juliá, M., Aguomet, J., 1998. Multisensor data integration and GIS analysis for natural hazard mapping in a semiarid area (Southeast Spain). Advanced Space Research, 21: 493-499.

Giannetti, F., Montanarella, L., Salandin, R., 2001. Integrated use of satellite images, DEMs, soil and substrate data in studying mountainous lands. International Journal of Applied Earth Observation and Geoinformation, 3: 25-29.

Gutman, G., Tarpley, D., Ignatov, A., Olson, S., 1995. The enhanced NOAA global land dataset from the advanced very high resolution radiometer. Bulletin of the American Meteorological Society. 76: $1141-1156$.

Haboudane, D., Bonn, F., Royer, A., Sommer, S., Mehl, W., 2002. Land degradation and erosion risk mapping by fusion of spectrally based information and digital geomorphometric attributes. International Journal of Remote Sensing, 18: 3795-3820.

Herweg, K., 1996. Field Manual for Assessment of Current Erosion Damage. SCRP Ethiopia, and Centre for Development and Environment, University of Berne: Berne; 69 pp.

Jetten, V., De Roo, A., Favis-Mortlock, D., 1999. Evaluation of field-scale and catchment-scale soil erosion models. Catena, 37: 521-541.

Jetten, V., Govers, G., Hessel, R., 2003. Erosion models: quality of spatial predictions. Hydrological Processes, 17: 887-900.

Kirkby, M.J., Imeson, A.C., Bergkamp, G., Cammeraat, L.H., 1996. Scaling up processes and models from the field plot to the watershed and regional areas. Journal of Soil and Water Conservation, 51: 391396. 
Koch, M., 2000. Geological controls of land degradation as detected by remote sensing: a case study in Los Monegros, north-east Spain. International Journal of Remote Sensing, 21: 457-473.

Koopmans, B.N., Forero, R.G., 1993. Airborne SAR and Landsat MSS as complementary information source for geological hazard mapping. ISPRS Journal of Photogrammetry and Remote Sensing, 48: 28-37.

Lambin, E.F., 1996. Change Detection at Multiple Temporal Scales: Seasonal and Annual Variations in Landscape Variables. Photogrammetric Engineering and Remote Sensing, 62(8): 931-938.

Ma, J.W., Xue, Y., Ma, C.F., Wang, Z.G., 2003. A data fusion approach for soil erosion monitoring in the Upper Yangtze River Basin of China based on Universal Soil Loss Equation (USLE) model. International Journal of Remote Sensing, 24: 4777-4789.

Mathieu, R., King, C., Bissonnais, Y., 1997. Contribution of multi-temporal SPOT data to the mapping of a soil erosion index: the case of the loamy plateaux of northern France. Soil Technology, 10(2): 99-110.

Mati, B.M., Morgan, R.P.C., Gichuki, F.N., Quinton, J.N., Brewer, T.R., Liniger, H.P., 2000. Assessment of erosion hazard with the USLE and GIS: a case study of the upper Ewaso Ng'iro North basin of Kenya. International Journal of Applied Earth Observation and Geoinformation, (2): 78-86.

Merrit, W.S., Letcher, R.A., Jakeman, A.J., 2003. A review of erosion and sediment transport models. Environmental Modelling and Software, 18: 761-799.

Metternicht, G.I., Fermont, A., 1998. Estimating erosion surface features by linear mixture modelling. Remote Sensing of Environment, 64: 254-265.

Metternicht, G.I., Zinck, J.A., 1998. Evaluating the information content of JERS-1 SAR and Landsat TM data for discrimination of soil erosion features. Photogrammetric Enginering and Remote Sensing, 53: 143-153. 
Metternicht, G.I., Gonzalez, S., 2005. FUERO: foundations of a fuzzy exploratory model for soil erosion hazard prediction. Environmental Modelling and Software, 20: 715-728.

Millward, A.A., Mersey, J.E., 1999. Adapting the RUSLE to model soil erosion potential in a mountainous tropical watershed. Catena, 38(2): 109-129.

Morgan, P.C., 1997. Erosión y conservación del suelo. Mundi-Prensa (Ed.), Madrid, 343 pp.

Muchoney, D., Haack, B., 1994. Change Detection for Monitoring Forest Defoliation. Photogrammetric Engineering and Remote Sensing, 60(10): 1243-1251.

Nadal-Romero, E., Regüés, D., Martí-Bono, C., Serrano-Muela, P., 2007. Badlands dynamics in the Central Pyrenees: temporal and spatial patterns of weathering processes. Earth Surfaces Processes and Landforms, 32(6): 888-904.

Nadal-Romero, E., Latron , J., Martí-Bono, C., Regüés. D., 2008. Temporal distribution of suspended sediment transport in a humid Mediterranean badland area: The Araguás catchment, Central Pyrenees. Geomorphology, 97: 601-616.

Oostwoud-Wijdenes, D.J., Poesen, J., Vandekerckhove, L., Ghesquiere, M., 2000. Spatial distribution of gully head activity and sediment supply along an ephemeral channel in a Mediterranean environment, Catena, 39: 147-167.

Pala, V., Pons, X., 1996. Incorporation of relief in polynomial-based geometric corrections. Photogrammetric engineering and Remote Sensing, 61(7): 935-944.

Pardini, G., 1996. Evoluzione temporale della microtopografia superficiale, della micromorfologia e della struttura in relazione ai processi di meteorizzazione nelle marne smectitiche di Vallcebre. Ph.D. Dissertation. Universidad de Barcelona (UB), Barcelona.

Paringit, E., Nadaoka, K., 2003. Sediment yield modelling for small agricultural catchments: Landcover parameterization based on remote sensing data analysis. Hydrological Processes, 17: 1845-1866. 
Pickup, G., Nelson, D.J., 1984. Use of Landsat radiance parameters to distinguish soil erosion, stability and deposition in arid central Australia. Remote Sensing of Environment, 16: 195-209.

Pickup, G., Chewings, V.H., 1988. Forecasting patterns of soil erosion in arid lands from Landsat MSS data. International Journal of Remote Sensing, 9: 69-84.

Pilesjo, P., 1992. GIS and Remote Sensing for Soil Erosion Studies in Semi-arid Environments. PhD thesis, Institutioner, Avhandlingar CXIV. Meddelanden fran Lunds Universitets Geografiska, Lunds, Sweeden, 203 pp.

Pueyo, Y., Begueria, S., 2007. Modelling the rate of secondary succession after farmland abandonment in a Mediterranean mountain area. Landscape and Urban Planning, 83(4): 245-254.

Regüés, D., 1995. Meteorización física en relación con los procesos de producción y transporte de sedimentos en un área acarcavada. Ph.D. Dissertation. Universidad de Barcelona (UB), Barcelona.

Regüés, D., Pardini, G., Gallart, F., 1995. Regolith behaviour and physical weathering of clayey mudrock as dependent on seasonal weather conditions in a badland area at Vallcebre, Eastern Pyrenees. Catena, 25(1-4): 199-212.

Reusing, M., Schneider, T., Ammer, U., 2000. Modelling soil loss rates in the Ethiopian Highlands by integration of high resolution MOMS-02/D2-stereo-data in a GIS. International Journal of Remote Sensing, 21(9): 1885-1896.

Riaño, D., Chuvieco, E., Salas, J., Aguado, I., 2003.Assessment of different topographic corrections in Landsat TM data for mapping vegetation types. IEEE Transactions on Geoscience and Remote Sensing, 41(5): 1056-1061.

Rode, M., Frede, H.G., 1997. Modification of AGNPS for agricultural land and climat condition in central Germany. J. of Environmental Quality, 26(1): 165-172. 
Schoorl, J.M., Sonneveld, M.P.W., Veldkamp, A., 2000. Three-dimensional landscape process modelling: the effect of DEM resolution. Earth Surface Processes and Landforms, 25: 1025-1034.

Shrimali, S.S., Aggarwal, S.P., Samra, J.S., 2001. Prioritizing erosionprone areas in hills using remote sensing and GIS—a case study of the Sukhna Lake sub-catchment, Northern India. International Journal of Applied Earth Observation and Geoinformation, 3: 54-60.

SIGPAC, 2003. Sistema de Información Geográfica de Parcelas Agrícolas de España. Ministerio de Agricultura, Pesca y Alimentación. En la WEB: http://www.mapa.es/es/sig/pags/sigpac/intro.htm

Singh, D., Herlin, I., Berroir, J.P., Silva, E.F., Simoes-Meirelles, P., 2004. An approach to correlate NDVI with soil colour for erosion process using NOAA/AVHRR data. Advances in Space Research, 33(3): 328-332.

Singhroy, V., 1995. SAR integrated techniques for geohazard assessment. Advanced Space Research, 1: 6778.

Singhroy, V., Mattar, K.E., Gray, A.L., 1998. Landslide characterisation in Canada using interferometric SAR and combined SAR and TM images. Advanced Space Research, 21: 465-476.

Solé, A., Calvo, A., Cerdà, A., Lázaro, R., Pini, R., Barbero, J., 1997. Influences of micro-relief patterns and plant cover on runoff related to processes in Badlands from Tabernas (SE Spain). Catena, 31: 28-38.

Symeonakis, E., Drake, N., 2004. Monitoring desertification and land degradation over sub-Saharan Africa. International Journal of Remote Sensing, 25: 573-592.

Szabo, J., Pasztor, L., SUBA, Z., VARALLYAY, G., 1998. Integration of remote sensing and GIS techniques in land degradation mapping. Proceeding of the 16th International Congress of Soil Science, Montpellier, France, pp. 63-75.

Torri, D., Rodolfi, G., 2000. Badlands in changing environments: an introduction. Catena, 40: 119-125. 
474 Tripathy, G.K., Ghosh, T.K., Shah, S.D., 1996. Monitoring of desertification process in Karanataka state of $475 \quad$ India using multi-temporal remote sensing and ancillary information using GIS. International Journal of Remote Sensing, 17: 2243-2257.

477 Valero-Garces. B.L., Navas, A., Machin, J., Walling, D., 1999. Sediment sources and siltation in mountain reservoirs: a case study from the central Spanish Pyrenees. Geomorphology, 28: 23-41.

Vermote, E.F., Tanré, D., Deuzé, J.L., Herman, M., Morcrette, J.J., 1997. Second simulation of the satellite signal in the solar spectrum, 6s: an overview. IEEE Transactions on Geoscience and Remote Sensing, 35(3): 675-686.

Vicente-Serrano, S.M., Beguería, S., Lasanta, T., 2006. Diversidad espacial de la actividad vegetal en 483 campos abandonados del Pirineo Central Español: análisis de los procesos de sucesión mediante imágenes Landsat (1984-2001). Pirineos, 161: 59-84.

485 Vicente-Serrano, S.M., Peréz-Cabello, F., Lasanta, T., 2008. Assessment of radiometric correction 486 techniques in analyzing vegetation variability and change using time series of Landsat images. Remote Sensing of Environment, DOI: 10.1016/j.rse.2008.06.011.

488 Vrieling, A., 2006. Satellite remote sensing for water erosion assessment: a review. Catena, 65: 2-18.

489 Vrieling, A., Sterk, G., Vigiak O., 2006. Spatial evaluation of soil erosion risk in the West Usambara 490 Mountains, Tanzania. Land Degradation and Development, 17(3): 301-319.

491 Warren, A., 2002. Land degradation is contextual. Land Degradation and Development, 13: 449-459.

492 Yair, A., Raz-Yassif, N., 2004. Hydrological processes in a small arid catchment: scale effects of rainfall and slope length. Geomorphology, 61: 155-169.

494 Zinck, J.A., López, J., Metternicht, G.I., Shrestha, D.P., Vázquez-Selem, L., 2001. Mapping and modelling mass movements and gullies in mountainous areas using remote sensing and GIS techniques. International Journal of Applied Earth Observation and Geoinformation, 3: 43-53. 
497 Table 1. Confusion matrix: $Y_{1}$, belonging to class $Y ; Y_{0}$, not belonging to class $Y$. Values $a$ and $d$ are the true 498 positives and true negatives, respectively, and $b$ and $c$ are the false positives (type I error) and false 499 negatives (type II error), respectively.

\begin{tabular}{llcc} 
& & \multicolumn{2}{c}{ Observed } \\
\cline { 3 - 4 } & & $Y_{1}$ & $Y_{0}$ \\
\hline Predicted & $Y^{\prime}{ }_{1}$ & $a$ & $b$ \\
& $Y^{\prime}{ }_{0}$ & $c$ & $d$ \\
\hline
\end{tabular}


501 Table 2. Contingence matrix of the classification applied to the training sample (proportion and total number 502 of pixels).

\begin{tabular}{|c|c|c|c|c|c|c|c|}
\hline & $\begin{array}{l}\text { Observed } \\
\text { categories }\end{array}$ & Badlands & $\begin{array}{c}\text { Conifers } \\
\text { forest }\end{array}$ & $\begin{array}{c}\text { Deciduous } \\
\text { forest }\end{array}$ & Grassland & Scrubland & $\begin{array}{c}\text { Total } \\
\text { (pixels) }\end{array}$ \\
\hline \multirow{5}{*}{ 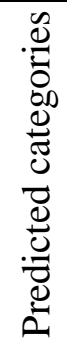 } & Badlands & 0.99 & 0 & 0 & 0 & 0.01 & 832 \\
\hline & $\begin{array}{l}\text { Conifers } \\
\text { forest }\end{array}$ & 0 & 0.94 & 0.01 & 0 & 0 & 1098 \\
\hline & $\begin{array}{l}\text { Deciduous } \\
\text { forest }\end{array}$ & 0 & 0.04 & 0.95 & 0 & 0.02 & 308 \\
\hline & Grassland & 0 & 0 & 0 & 0.99 & 0 & 300 \\
\hline & Scrubland & 0.01 & 0.02 & 0.04 & 0.01 & 0.97 & 1151 \\
\hline & Total (pixels) & 835 & 1164 & 247 & 298 & 1145 & 3689 \\
\hline
\end{tabular}


504 Table 3. Confusion matrix among categories (proportion and total number of pixels).

\begin{tabular}{|c|c|c|c|c|c|c|c|c|c|}
\hline & $\begin{array}{r}\text { Observed } \\
\text { categories }\end{array}$ & Badlands & $\begin{array}{c}\text { Conifers } \\
\text { forest }\end{array}$ & $\begin{array}{c}\text { Deciduous } \\
\text { forest }\end{array}$ & Grassland & Scrubland & $\begin{array}{c}\text { Total } \\
\text { (pixels) }\end{array}$ & $\begin{array}{c}\text { Commission } \\
\text { error }(\%)\end{array}$ & Specificity \\
\hline \multirow{9}{*}{ 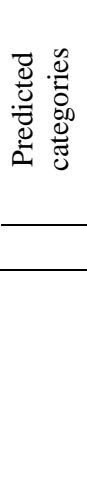 } & Badlands & 0.87 & 0.00 & 0.00 & 0.02 & 0.05 & 70 & 22.86 & 0.771 \\
\hline & Conifers forest & 0.00 & 0.75 & 0.05 & 0.00 & 0.00 & 16 & 25.00 & 0.750 \\
\hline & Deciduous forest & 0.00 & 0.25 & 0.82 & 0.00 & 0.00 & 64 & 6.25 & 0.938 \\
\hline & Grassland & 0.03 & 0.00 & 0.00 & 0.86 & 0.11 & 132 & 25.76 & 0.742 \\
\hline & Scrubland & 0.10 & 0.00 & 0.12 & 0.12 & 0.84 & 264 & 10.98 & 0.890 \\
\hline & & & & & & & Total & 18.17 & 0.818 \\
\hline & Total (pixels) & 62 & 16 & 73 & 114 & 281 & 546 & \multirow{2}{*}{\multicolumn{2}{|c|}{ Total }} \\
\hline & $\begin{array}{c}\text { Omission error } \\
(\%)\end{array}$ & 12.90 & 25.00 & 17.81 & 14.04 & 16.37 & & & \\
\hline & Sensitivity & 0.871 & 0.750 & 0.822 & 0.860 & 0.836 & & \multicolumn{2}{|c|}{0.823} \\
\hline
\end{tabular}

505 


\section{Figure captions}

507 Figure 1. Location of the study area: A, area of the Landsat scene; B, location of badland areas on marls $508\left(236 \mathrm{~km}^{2}\right)$.

509 Figure 2. Digital terrain model (DTM) of the study area.

510 Figure 3. Thornthwaite diagram in Campo, Huesca: T, monthly average temperature $\left({ }^{\circ} \mathrm{C}\right)$; $\mathrm{P}$, monthly 511 average precipitation (mm); ET, potential evapotranspiration (mm); WS, hydric balance (mm; P-ET).

512 Figure 4. Spectral signature for each of the thematic categories. The vertical bars indicate the standard 513 deviation with respect to the average reflectivity.

514 Figure 5. Land cover map based on supervised classification using the maximum likelihood method.

515 Figure 6. Detail of the transition areas between badlands and forest (conifers and deciduous forest).

516 Figure 7. Spectral distance map (UD: digital units) of the badlands category in relation to other categories.

517 Figure 8. ROC curve for classification of the active erosion areas (badlands). The central segmented line 518 represents a model without predictive capacity. Therefore, the further the ROC curve is from the central line 519 the greater is the discriminatory capacity of the model. U1 and U2 indicate the classification thresholds 520 selected for assessment of active erosion and erosion risk areas, respectively.

521 Figure 9. Active erosion (badlands) and erosion risk maps, obtained from the spectral distance map and the 522 classification threshold.

523 Figure 10. Percentage distribution of hillside aspect: A, total area; B, badland areas; C, erosion risk areas.

524 Figure 11. Frequency histogram of hillside slope: A, total area; B, badland areas; C, risk erosion areas. 


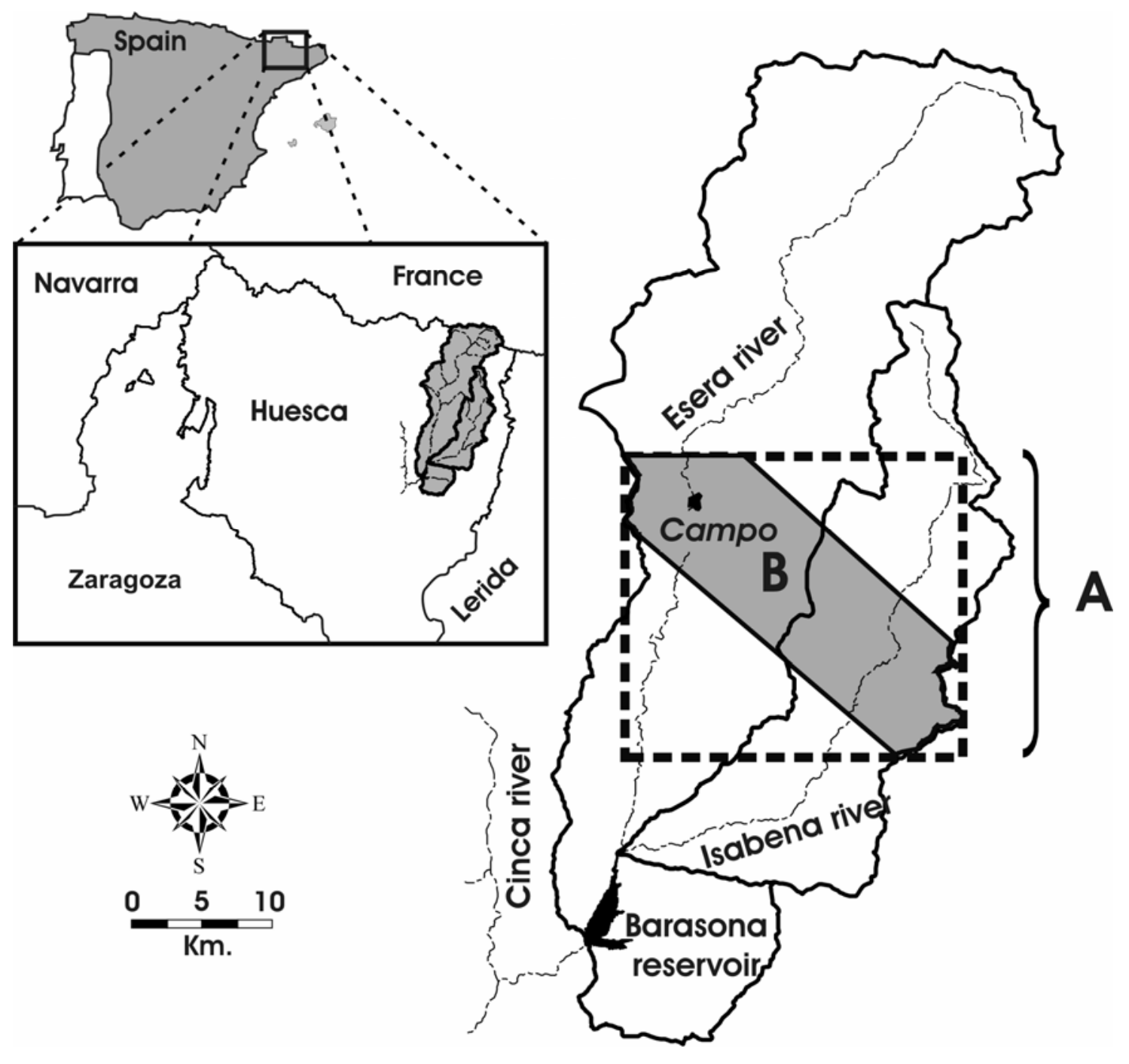




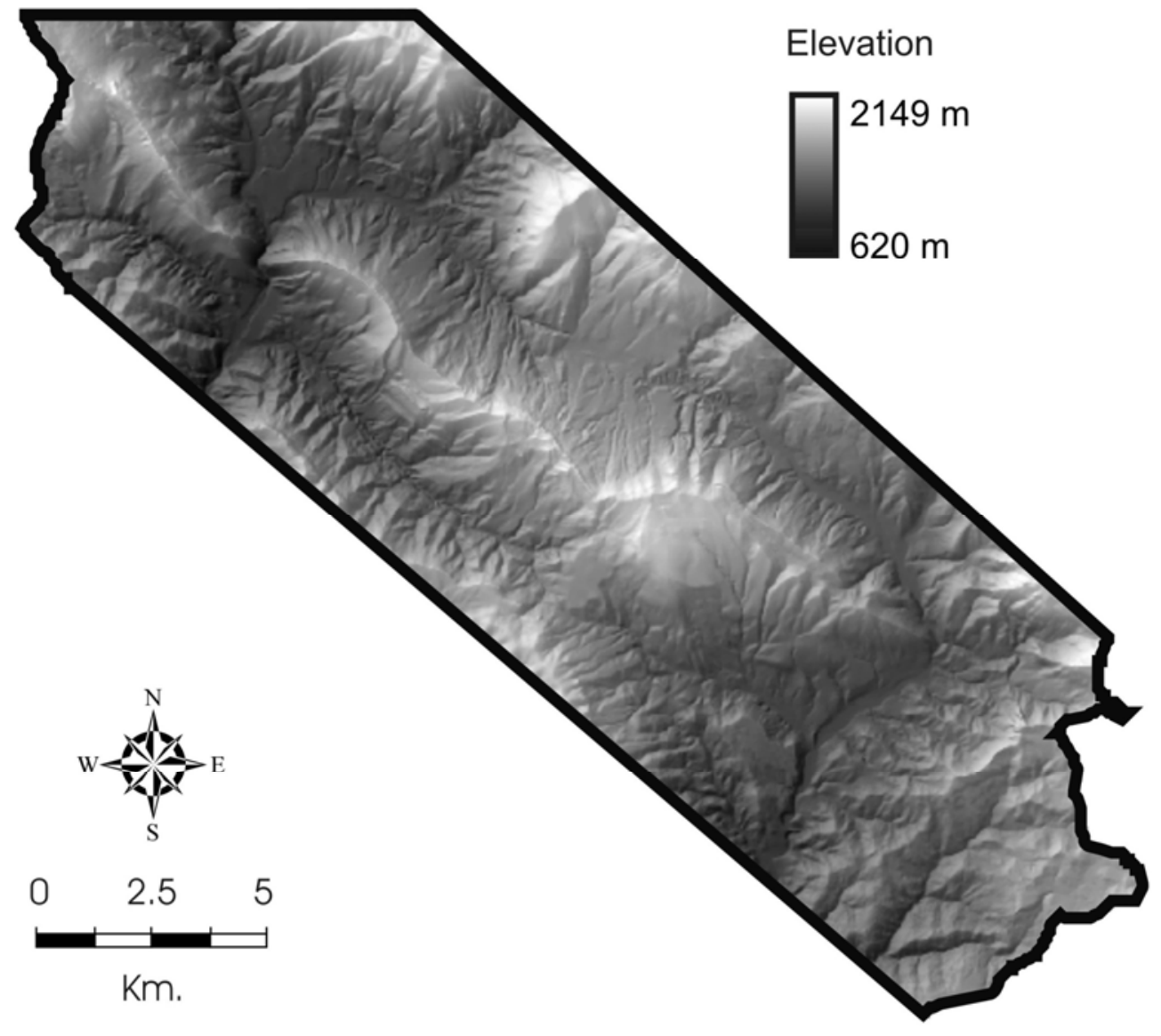

529

530

531

Fig. 2 


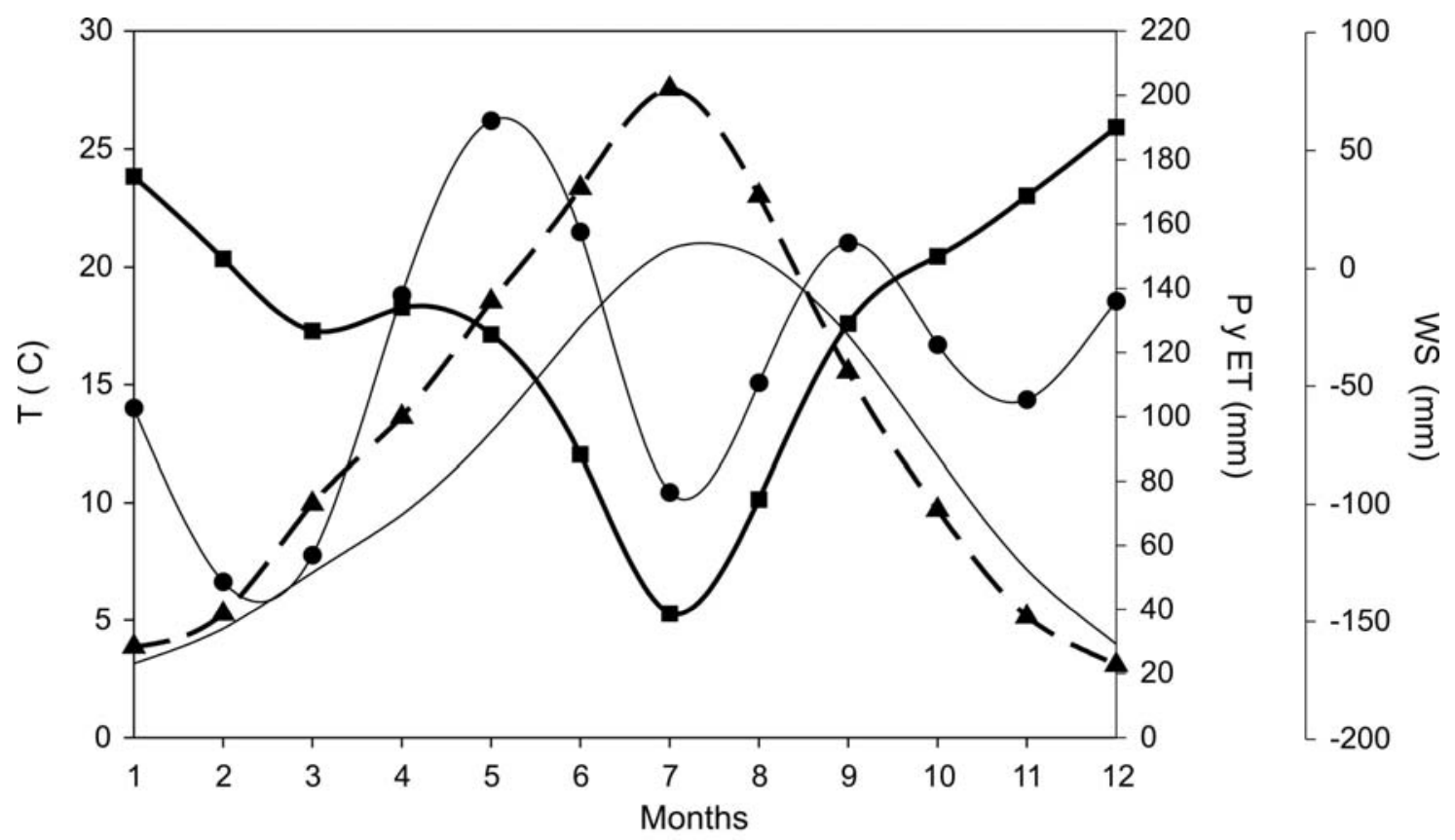

532 $\mathrm{T}(\mathrm{C})$ WS (P-ET)

533

534

535

Fig. 3 

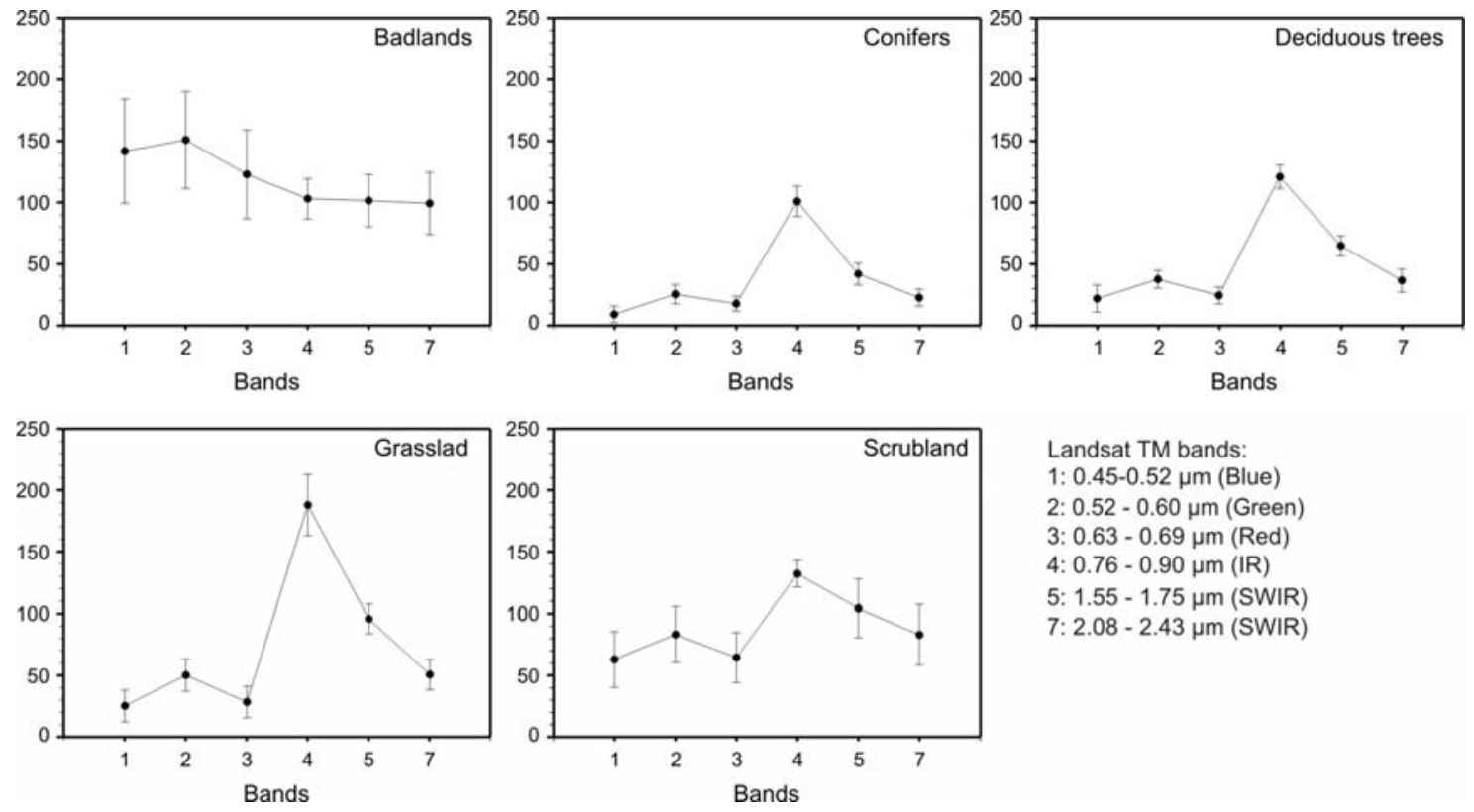

Landsat TM bands:

1: 0.45-0.52 $\mu \mathrm{m}$ (Blue)

2: $0.52-0.60 \mu \mathrm{m}$ (Green)

3: $0.63-0.69 \mu \mathrm{m}$ (Red)

4: $0.76-0.90 \mu \mathrm{m}$ (IR)

$5: 1.55-1.75 \mu \mathrm{m}$ (SWIR)

7: $2.08-2.43 \mu \mathrm{m}$ (SWIR) 


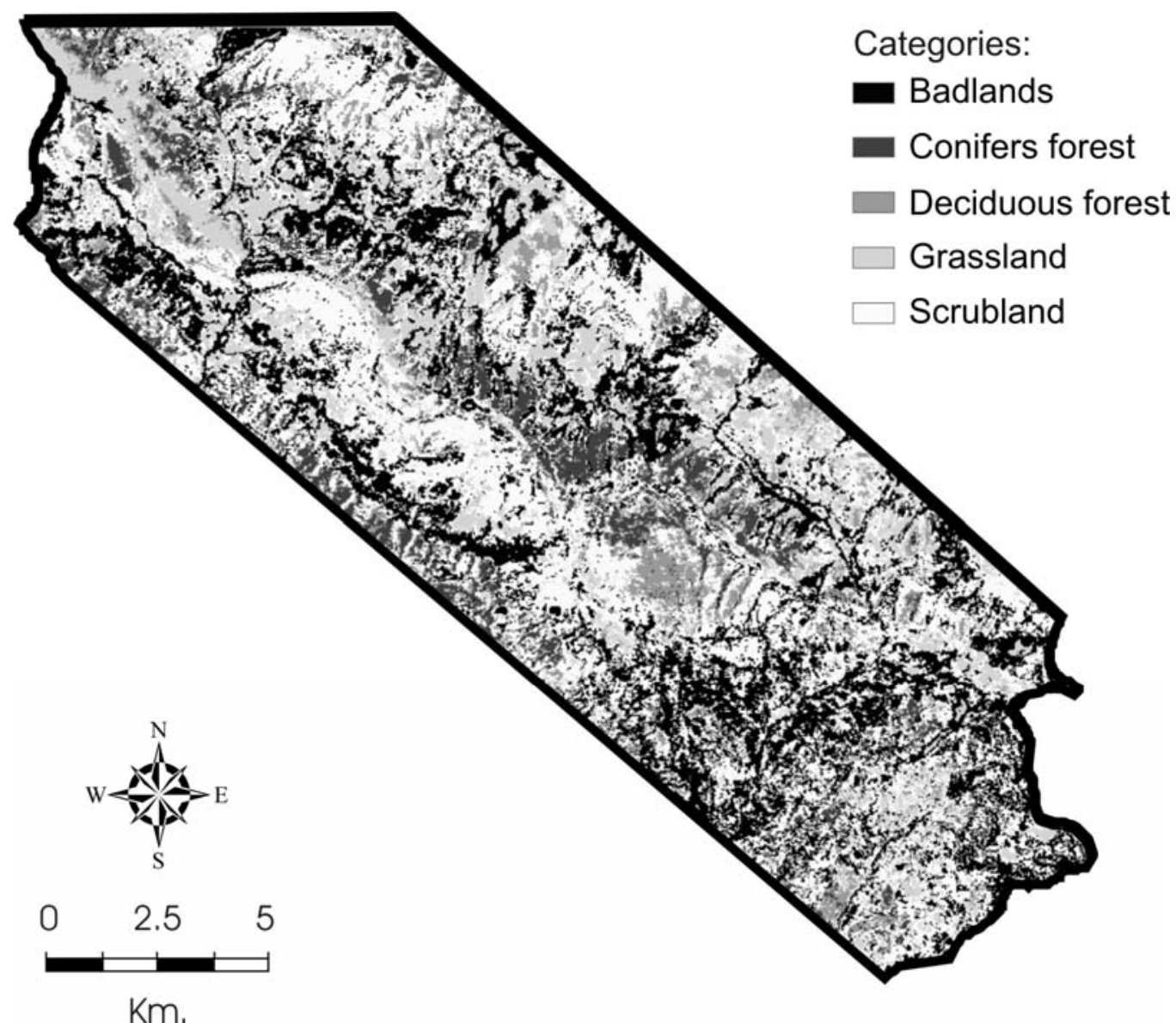




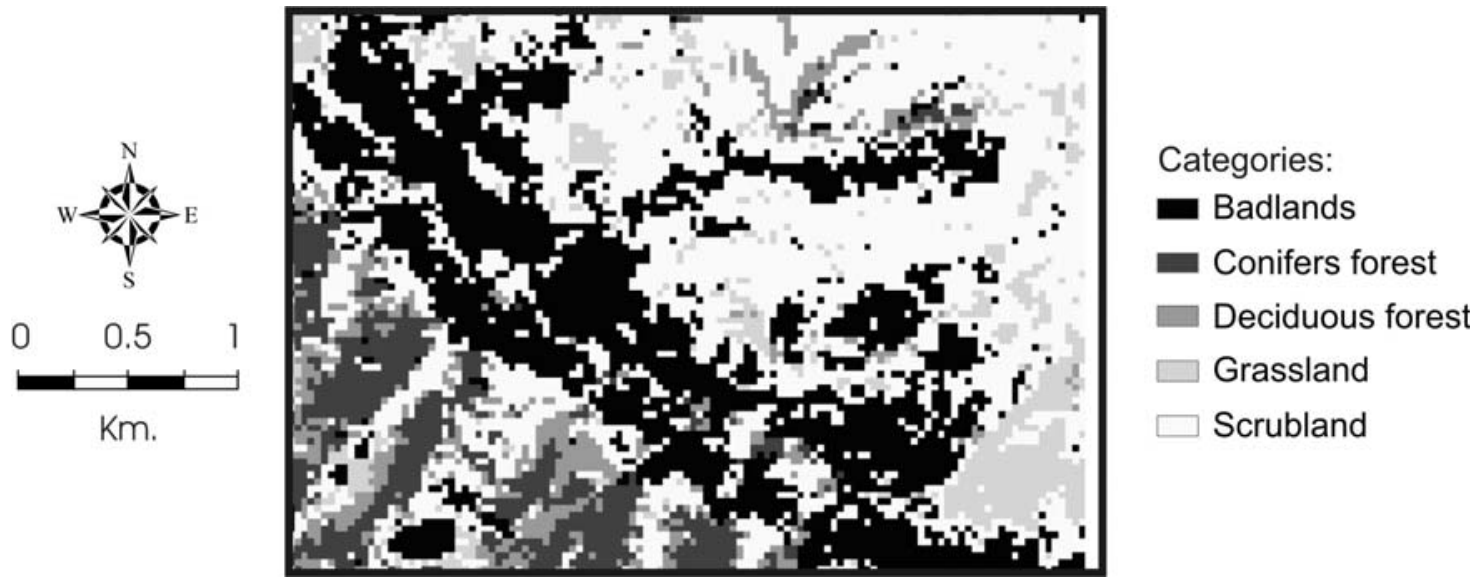

544

545

546

Fig. 6 


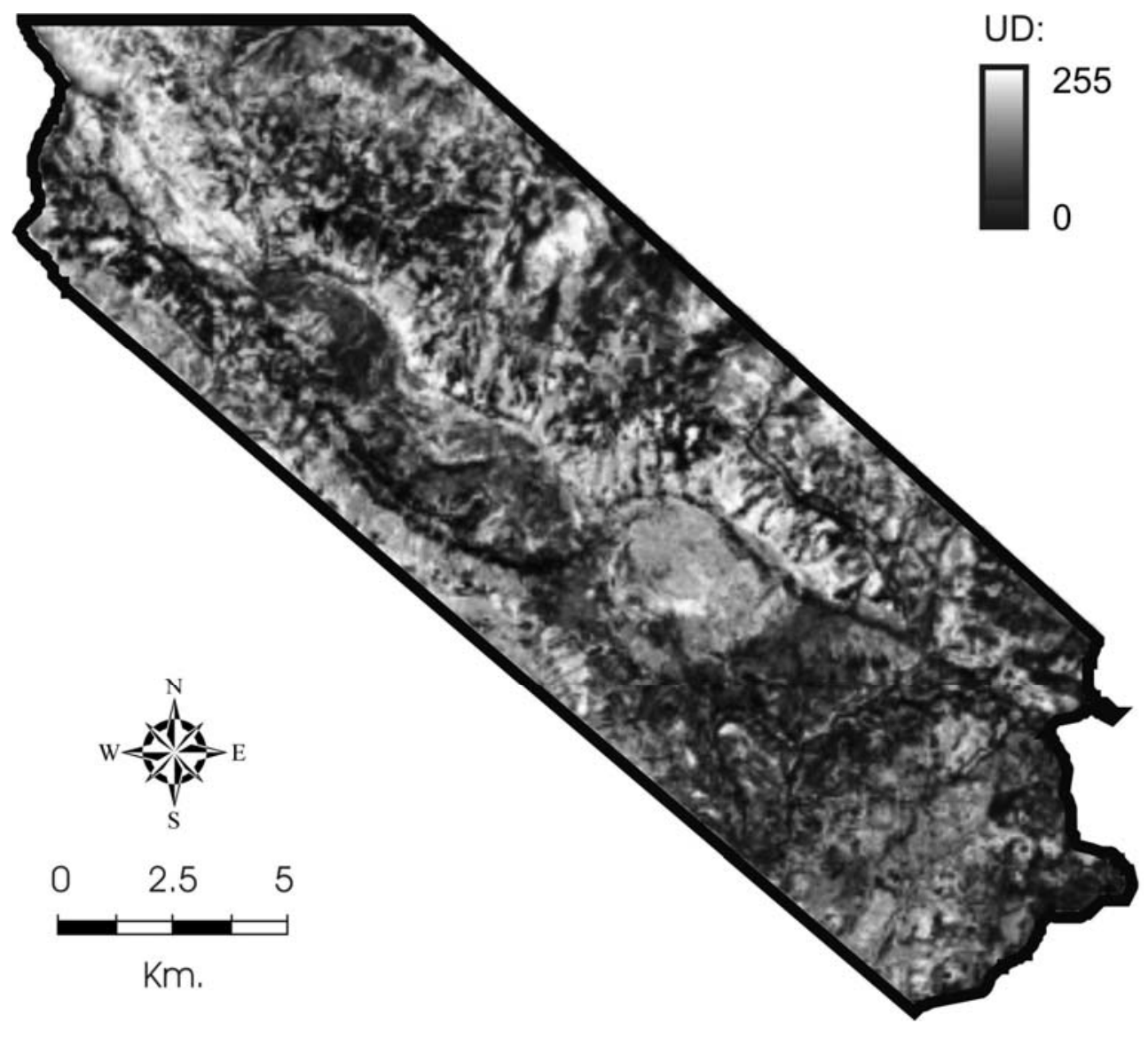

547

548

549

550

Fig. 7 


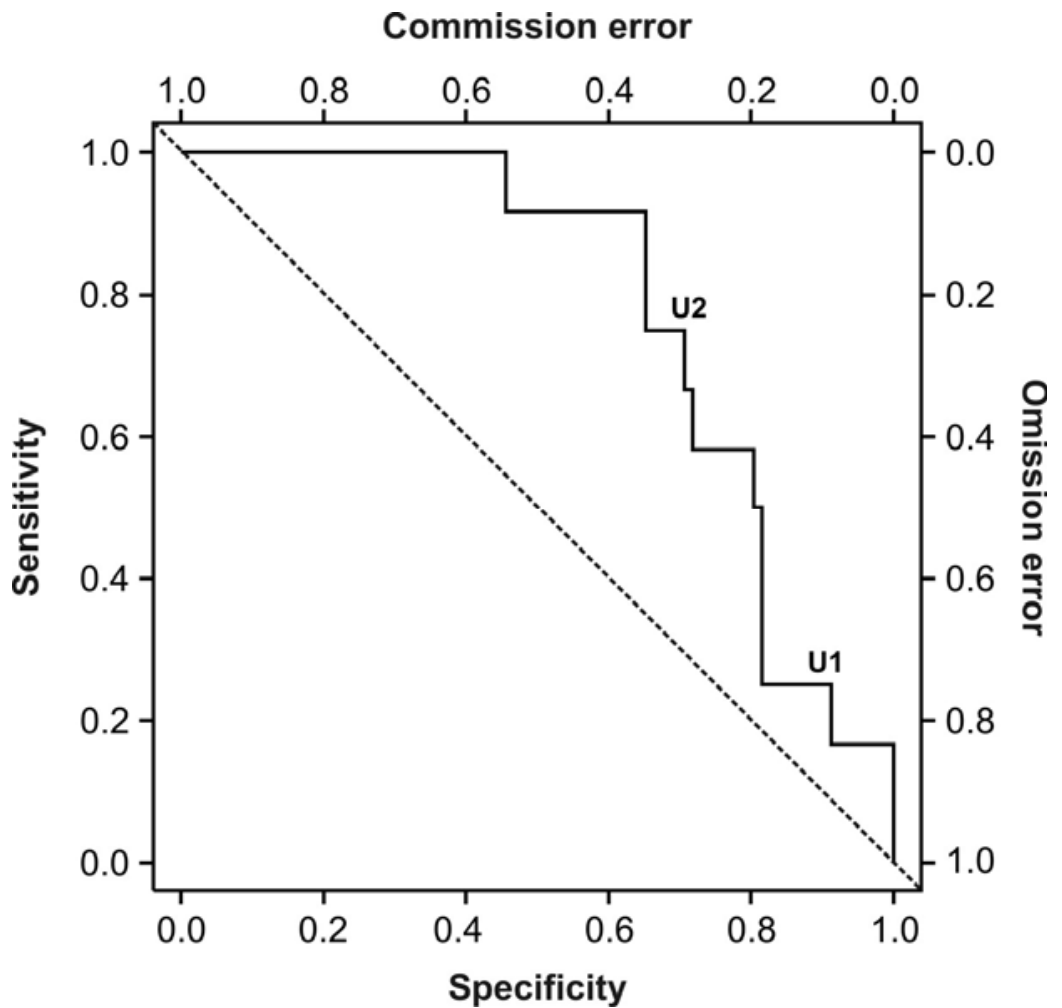

551

552

553

554

Fig. 8 


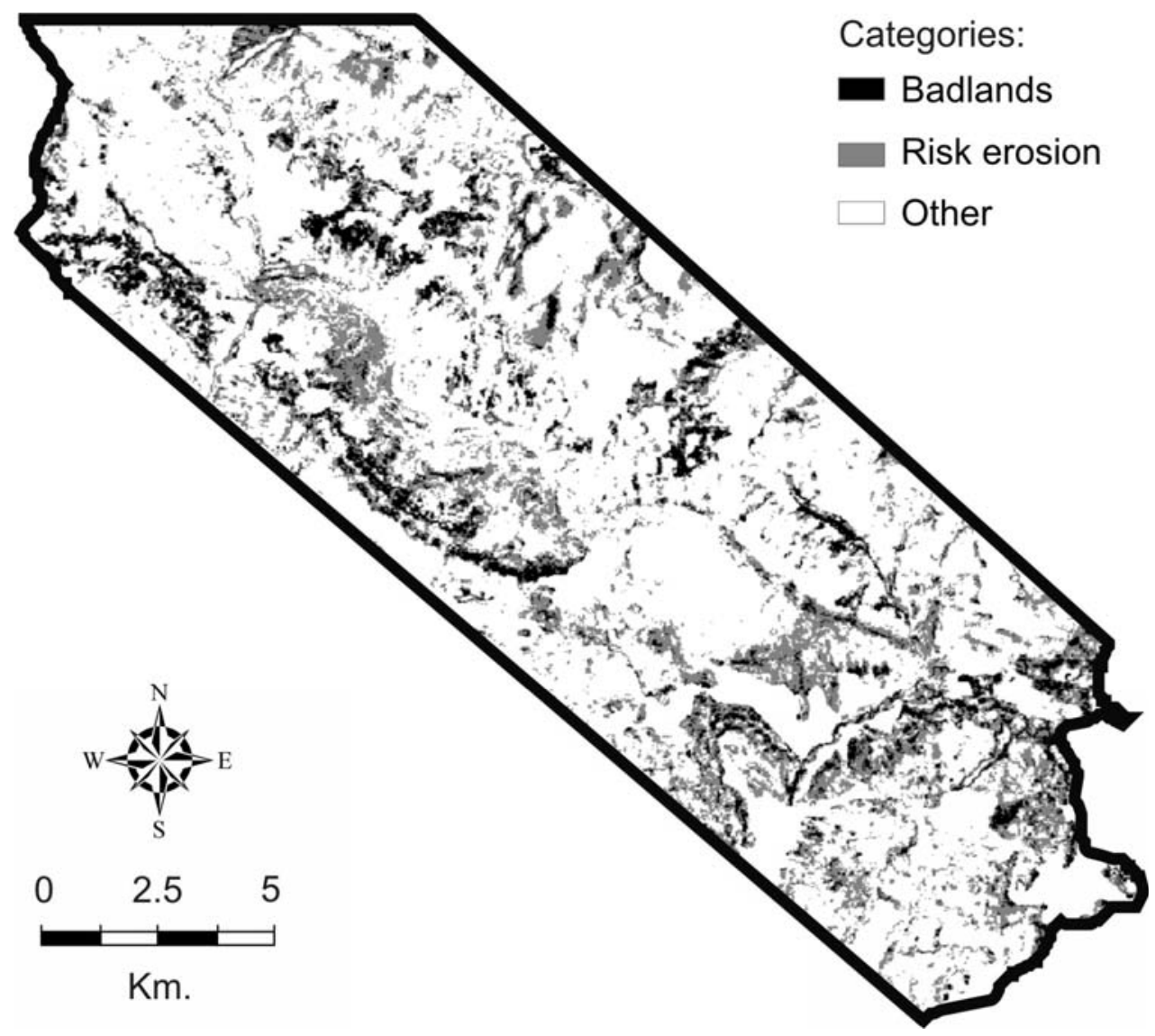



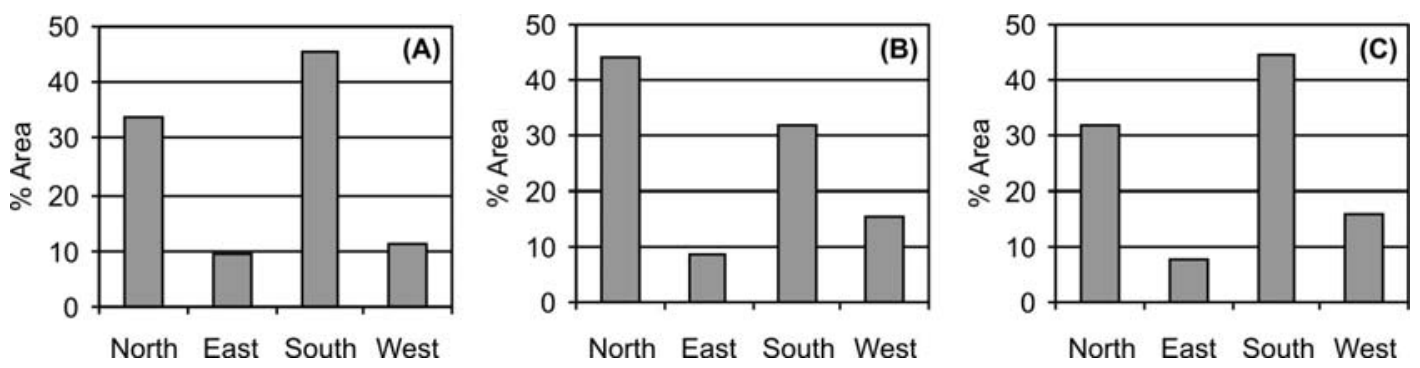

560

561

562

Fig. 10 
Slope $\left({ }^{\circ}\right)$

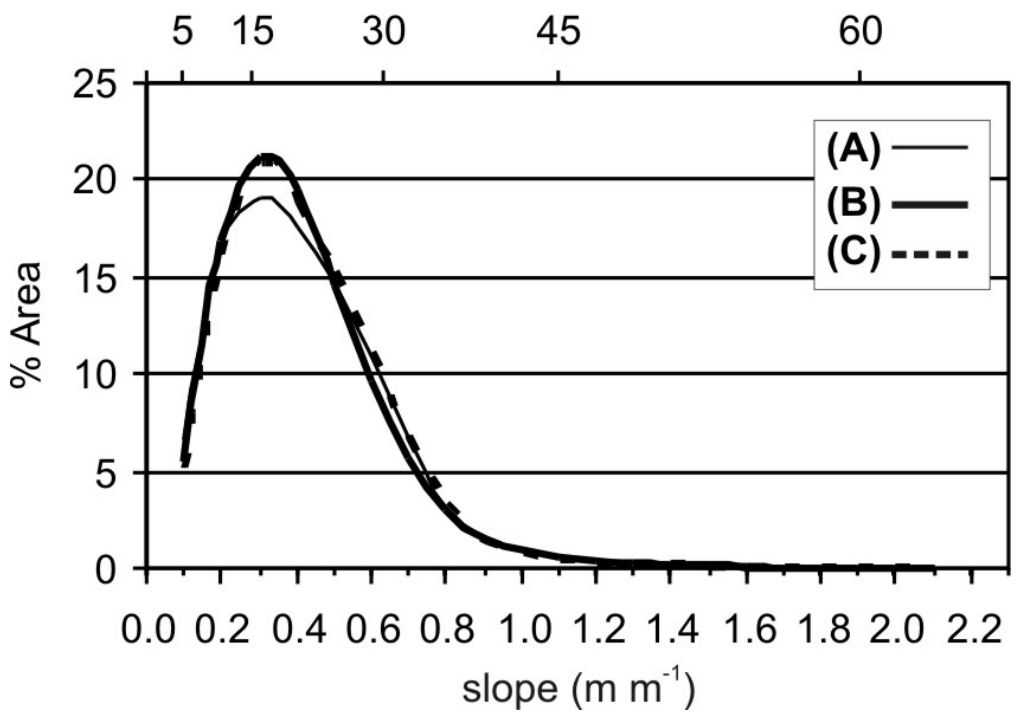

564

565

Fig. 11 